\title{
Methods for safety-related weighting and comparative assessment in the site selection process (MABeSt)
}

\author{
Gerd Frieling $^{1, \mathrm{a}}$, Klaus Fischer-Appelt ${ }^{2, \mathrm{a}}$, Ute Maurer-Rurack ${ }^{1}$, Thomas Beuth ${ }^{1, \mathrm{a}}$, and Guido Bracke ${ }^{1, \mathrm{a}}$ \\ ${ }^{1}$ Federal Office for the Safety of Nuclear Waste Management (BASE), Wegelystr. 8, 10623 Berlin, Germany \\ ${ }^{2}$ RWTH Aachen University, Chair for Repository Safety, Wüllnerstraße 2, 52062 Aachen, Germany \\ ${ }^{a}$ formerly at: GRS gGmbH, Schwertnergasse 1, 50667 Cologne, Germany
}

Correspondence: Gerd Frieling (gerd.frieling@bfe.bund.de)

Published: 10 November 2021

\begin{abstract}
The Federal Office for the Safety of Nuclear Waste Management (BASE) supervises the site selection process in Germany and in particular has the task to review the proposals made by the implementer (Federal Company for Radioactive Waste Disposal, BGE) for determining the siting regions and sites in accordance with $\S \S 14,16$ and 18 of the German Repository Site Selection Act (StandAG).

To determine the siting regions from the sub-areas and the sites from the siting regions, it is likely that safetyrelated weighting of the results from the application of the geoscientific weighting criteria ( $\$ 24$ StandAG) and the application of the preliminary safety investigations ( $\$ 27$ StandAG) are necessary.

In order to be able to assess and evaluate the proposals of the BGE with respect to the methodological procedure for determining the siting regions and sites, the research project "Methods for safety-related weighting and comparative assessment in the site selection process" (MABeSt) was initiated by BASE. The objective of the research project was to research and explain the state of the art in science and technology (S\&T) with respect to safety-oriented weighting and comparative assessment methods and their potential applicability for the selection of siting regions and sites in the site selection process. The status of S\&T for safety-oriented weighting and comparative assessment methods was examined and evaluated with respect to site selection procedures for repositories in Germany and abroad (e.g. Switzerland) and also to methodological approaches from other topics (e.g. landfill site selection). The site selection process represents a multicriteria decision problem, which means that methods from the research field of decision theory appear to be suitable. In particular, methods from the multiattribute decision making/aid (MADM) category were identified as suitable and their potential applicability was examined and evaluated. Specific challenges (e.g. data uncertainties, different scales of evaluation criteria) for the relevant procedural steps of the site selection process were taken into account.

We present the results and conclusions of the project MABeSt (funding code/4718F13001) carried out by GRS $\mathrm{gGmbH}$ and initiated and funded by BASE.
\end{abstract}

Kurzfassung. Das BASE (Bundesamt für die Sicherheit der nuklearen Entsorgung) überwacht den Vollzug des Standortauswahlverfahrens in Deutschland und hat insbesondere die Aufgabe, die Vorschläge der Vorhabenträgerin (Bundesgesellschaft für Endlagerung - BGE) zur Ermittlung der Standortregionen und Standorte, gemäß §§ 14, 16 und 18 nach dem Gesetz zur Suche und Auswahl eines Standortes für ein Endlager für hochradioaktive Abfälle (im Folgenden StandAG) zu prüfen.

Zur Ermittlung der Standortregionen aus den Teilgebieten und den Standorten aus den Standortregionen, sind voraussichtlich sicherheitsgerichtete Abwägungen der Ergebnisse aus der Anwendung der geowissenschaftlichen Abwägungskriterien ( $(24$ StandAG), sowie der vorläufigen Sicherheitsuntersuchungen ( 27 StandAG) erforderlich

Um die Vorschläge der BGE in Bezug auf die methodische Vorgehensweise zur Ermittlung der Standortregionen und Standorte einzuschätzen und bewerten zu können, wurde vom BASE das Forschungsvorhaben MABeSt initiiert. Ziel des Forschungsvorhabens war es, den Stand von Wissenschaft und Technik (W\&T) 
hinsichtlich sicherheitsgerichteter Bewertungs- und Vergleichsmethoden zu recherchieren und deren potenzielle Anwendbarkeit für die Auswahl von Standortregionen und Standorten im Standortauswahlverfahren zu bewerten.

Der Stand von W\&T für sicherheitsgerichtete Bewertungs- und Vergleichsmethoden wurde mit Bezug zu Standortauswahlverfahren für Endlager im In- und Ausland (z. B. Schweiz) und auch anhand methodischer Herangehensweisen aus anderen Fachgebieten (z. B. der Deponiestandortauswahl) gesichtet und ausgewertet. Die Standortauswahl stellt ein multikriterielles Entscheidungsproblem dar, wodurch Methoden aus dem Forschungsfeld der Entscheidungstheorie als geeignet erscheinen. Insbesondere Methoden aus der Kategorie MADM („Multi Attribute Decision Making/aid“) wurden als geeignet identifiziert und deren potenzielle Anwendbarkeit, unter Berücksichtigung der spezifischen Herausforderungen (z. B. Datenungewissheiten, unterschiedliche Skala der Bewertungskriterien) für die relevanten Verfahrensschritte des Standortauswahlverfahrens, untersucht und bewertet.

Der Vortrag soll die Erkenntnisse und Ergebnisse des von der GRS gGmbH durchgeführten und vom BASE initiierten und geförderten Projekts „Methoden für sicherheitsgerichtete Abwägungen und vergleichende Bewertungen im Standortauswahlverfahren (MABeSt)“ (Förderkennzeichen/4718F13001) aufzeigen.

Financial support. This research has been supported by the Bundesamt für Naturschutz (grant no. 4718F13001). 